\section{International Scientific Journal Theoretical \& Applied Science}

p-ISSN: 2308-4944 (print) e-ISSN: 2409-0085 (online)

Year: $2014 \quad$ Issue: 12 Volume: 20

Published: $30.12 .2014 \quad$ http://www.T-Science.org
Sergey Iosifovich Tatarinov

Ph.D. candidate of historical sciences, Associate Professor of Engineering Pedagogy Educational and Scientific Professional Pedagogical Institute of Ukrainian Engineering and Pedagogical Academy, Ukraine, Donetsk region, Artemovsk tatbronza@yandex.ua

SECTION 13. Geography. History. Oceanology.

Meteorology.

\title{
THE INFLUENCE OF THE DONBASS ZEMSTVOS ON "SALOON BUSINESS" IN THE DONBASS REGION AS A SOURCE OF BUDGET REPLENISHMENT AND THE FIGHT AGAINST ALCOHOLISM
}

Abstract: The materials of Ekaterinoslav province's the Bakhmut and Mariupol counties statistics on the number of commercial Wine and Spirits profile establishments, excise duties and taxes collection to the local Zemstvos and Dumas budgets, "saloon business" legal regulation by the Zemstvos and the role of the police are studied in the article. The Zemstvo's assessment of dangers of heavy drinking and numerous attempts to struggle with alcoholism, management and alcohol trade bans during the late 19th century and the 1st World War are analyzed in the article.

Key words: pub, excise, wine, vodka, heavy drinking.

Language: Ukrainian

Citation: Tatarinov SI (2014) THE INFLUENCE OF THE DONBASS ZEMSTVOS ON "SALOON BUSINESS" IN THE DONBASS REGION AS A SOURCE OF BUDGET REPLENISHMENT AND THE FIGHT AGAINST ALCOHOLISM. ISJ Theoretical \& Applied Science 12 (20): 65-71. http://dx.doi.org/10.15863/TAS.2014.12.20.15

\section{ВЛИЯНИЕ ЗЕМСТВ ДОНБАССА "ПИТЕЙНОЕ ДЕЛО" ДОНБАССА КАК ИСТОЧНИК ПОПОЛНЕНИЯ БЮДЖЕТА И БОРЬБЫ С ПЬЯНСТВОМ}

Аннотация: В статье исследуются материаль статистики по Бахмутскому и Мариупольскому уездам Екатеринославской губернии, о числе торговых заведений винно-водочного профиля, сборы акцизов и налогов в бюджеты местных земств и Дум, правовое регулирование «питейного дела» государством, роль полиции. Проанализированы оценки вреда пьянства земскими деятелями и многочисленные попытки борьбы с ним, регулирования и запретов торговли спиртным в конце 19 в. и в период 1-й Мировой войны.

Ключевые слова: питейная лавка, акцииз, вино, водка, пьянство.

\section{ВПЛИВ ЗЕМСТВ ДОНБАСУ НА «ПИТНУ СПРАВУ» ЯК ДЖЕРЕЛО ПОПОВНЕННЯ БЮДЖЕТІВ ТА БОРОТЬБА 3 ПИЯЦТВОМ}

Анотація: У статті досліджуються матеріали статистики по Бахмутському і Маріупольському повітах Катеринославської губернії, про число торгових закладів винно-горілчаного профілю, збори акизиів і податків до бюджетів місиевих земств і Дум, правове регулювання «питної справи» земиями, роль поліції. Проаналізовано оцінки шкоди пияцтва земськими діячами і численні спроби боротьби з ним, регулювання та заборон торгівлі спиртним у кінияі $19 \mathrm{~cm}$. і в період 1-ї Світової війни.

Ключові слова: питна лавка, акции, вино, горілка, пияитво

Впливу правоохоронних та фіскальних органів на питну справу Росії та України до 1917 p. в останній час присвячені праці О. Ярмиша $[1,2]$, В. Гончарука [3] . Серед досліджень з історії Донеччини взагалі, ролі «горілчаного» акцизу в наповненні місцевих бюджетів, зокрема немає праць $з$ історії дорадянської «питної справи».
«Питна справа» мала значний вплив на формування бюджетів Бахмутського повіту та Бахмуту, але це питання раніше дослідниками історії Донбасу не розглядалося.

У Російській імперії значну частину прибутків державної казни давала питна справа, податки та акцизи жорстко регламентувалися [4$14]$.

ISPC European Research, 
Перша згадка про «питну справу» міститься у Наказі, який купці Бахмуту, президент і міський Голова Тимофій Назаров, бургомістр Осип Грошев, ратман Петро Михайлов, цивільний староста Іван Четвериков, купець Парфен Гаврилов і ще 30 купців, відставні сержанти бахмутського батальйону Малєєв і Півнів, каптенармус Шеталов склали 311 «кондицій до Комісії з Уложення Катерини II у 1767 р. [15, c.154-159] . Купці просили дозволити купівлю земель під посадку лісу, заготівлю дрів для винокуріння і встановити звичайний акциз з відра горілки.
Соляна контора віддала питну справу одному купцю Парфену Гаврилову (він був серед авторів Наказу...), після закінчення терміну потрібно віддати Магістрату право розподіляти питну справу між купцями.

У $1859-62$ рр. в Бахмуті було 8 горілчаних складів, у повіті - 11 [16].

Винокурінням у повіті займалося 5 заводів 3 об'ємом 1,5 мільйони відер. У загальній сумі податків повіту у 1867 р. [17] у 23436 руб. «питна справа» давала:

Податки «питної справи»

Таблиця 1

\begin{tabular}{|c|c|}
\hline за 491 питні патенти & 1658 руб. \\
\hline з 19 виннх складів & 190 руб. \\
\hline з 7 складів ренських вин & 112 руб. \\
\hline з 76 погребів російських вин & 76 руб. \\
\hline з ярмаркових виставок алкогольних напоїв & 410 руб. \\
\hline 10 винокурних заводів & 12,6 тис. руб. [17] \\
\hline
\end{tabular}

Про неабияку популярність у портовому Маріуполі питних місць свідчать матеріали повітових земств.«Начиная с субботы сразу после получения заработной платы, практически до вечера понедельника кабаки в Мариуполе были заполнены людьми. Гулянки сопровождались постоянными дикими криками, песнями и бранью. Конец этому наступал когда все деньги были пропиты и владелец кабака больше в долг не давал. Некоторые работники после гулянок не выходили на роботу. Нередко после пьянок на работе происходили травмы и беспорядок, иногда даже грабежи с убийствами» [18].

Катеринославська губернська земська управа у 1878 р. відзначала, що найбільше грошнй пропило населення Маріупільського повіту -575
000 руб.; у Маріїнській волості 256 тис. руб.; у Волонтерівці 127 тис. руб.; Сретенсбкій волості 113 тис. руб. ; від 75 до 100 тис.руб. витрачено у Миколаївській, Благотівській, Сартанській, Олександроневській і Каранській; до 75 тис. руб. у Петрівській, Мало-Янисольській, Михайлівській ; до 50 тис.руб. у Ялтинській, Новоспасівській,Івановській від 20 до; 25 тис. руб. пропили мешканці волостей Покровської, Багатирської, Мангушскої,Темрюкської, Елисаветської, Камарської, Бешівської, , СтароКременчикської, Романовської, Петропавлівської [18].

У Маріупольському повіті у 1878 р.було витрачено на горілчані вироби 1903420 руб.

Марільпольський земський бюджет:

Таблиця 2

\section{Витрати на горілку}

\begin{tabular}{|c|c|}
\hline Призначення витрат & Сума \\
\hline земський бюджет & 1082273 руб. \\
\hline податки з населення & 663350 руб. \\
\hline народна освіта & 479699 руб. \\
\hline медицина & 209648 руб. \\
\hline агрономія & 94327 руб. \\
\hline ветеринарія & 62770 руб. \\
\hline
\end{tabular}

Витрати на алкоголь на одного чоловіка становили на рік від 2,35 руб. в Романівсьькій волості до 12,18 руб. в Майорській волості і 25,78 руб. в Маріінській волості.
Земський лікар Маріупольського повіту С.Ф. Казанський писав: « За долгие годы пьянства в нашем отношении к этому явлению уже сформировался определенный иммунитет и о вреде алкоголизма мы чаще говорим шутя, иногда 
удивляясь количеству выпитого, иногда сожалея о вреде который можно этим причинить, вред степень которого полностью не учитываем». степень вреда от алкоголя колоссальна. Ведь приведенные цифры затрат населения на алкогольные напитки были слишком впечатляющими. По мнению врача «причины алкоголизма конечно являются чрезвычайно сложными... Из приведеных цифр ясно одно, что вред от алкоголизма для уезда огромен и что борьба с ним должна начаться» [19].

Цікавим було те, що гласні Маріупільського земства вважали, що «... ярмарок в уезде существует много, особенной потребности в открытии новых нет, меж тем благодаря им сильно развивается пьянство» .

У повіті 1871 р. була овідкрита ярмарка в Малій Янисолі, в 1872 р. у Сартані, Новом Кременчику. У $1872-76$ рр. ярмарки у Каракубі, Стилі, Великій Янісолі, Ігнатівці, у 1880-1891 pp. ярмарки біли відкриті у с. Бешевому, Богатиру,К арані, Ласпі, Мангуші, Урзуфі. На початку XX ст. Маріупольський повіт занимав 4 місце у губернії. У 1913 г. відбувалося більше 80 ярмарок 5-денні ярмарки, недіотні.

Земські діячі вважали, що «именно большое количество ярмарок провоцировало безответственность и пьянство крестьян и привело к полному падению сельского хозяйства» [20].

У Бахмутському повіті масове пияцтво не було поширеним, алкогольні напої споживалися найчастіше на свята. Статистичні відомості по Бахмутському повіту свідчать, що в 1884 р. одна корчма доводилася аж на 458 осіб, а в 1892 р. 1 корчма доводилося на 570 осіб.

У 80 роки XIX століття у повіті було винокурень 14. Вино-горілчаною продукцією торгували 12 кабаків, 2 трактири , 20 питних лавок та складів, 6 постоялих дворів [218, с.123].

\section{Перелік закладів питної справи}

Таблиця 3

\begin{tabular}{|c|c|c|}
\hline Заклад торгівлі & Місто & повіт \\
\hline Чаркові & 11 & 124 \\
\hline Ренських вин & 7 & 337 \\
\hline Питні будинки & 69 & 75 \\
\hline Російських вин & 1 & 3 \\
\hline Трактирів & 5 & - \\
\hline Буфетів & 4 & 8 \\
\hline У заїжджих дворах & 3 & 286 \\
\hline На розлив на ярмарках & 196 & \\
\hline
\end{tabular}

Збори з роздрібної торгівлі складали:

Таблиця 4

Збори з роздрібної торгівлі

\begin{tabular}{|c|c|}
\hline з рюмочної & 5 руб. \\
\hline з ренського погребу & 3 руб. \\
\hline з горілчаного підвалу & 20 руб. \\
\hline з питного будинку & 5 руб. \\
\hline з розливу на ярмарку по & 1 руб. [21, с.124] \\
\hline
\end{tabular}

Виділялися Отрадівський винокурний завод Хренова (272,6 тис. відер горілки), Ільїнівський Станкевича (339,5 тис.відер). Прибуток акцизу від діючих 5 заводів становив 179,9 тис.руб.

У 1874 р. Думи та земства отримали право визначати кількість місць продажу та забороняти торгівлю спиртними напоями в тих чи інших місцевостях.

Починаючи 3 реформи управління "питною справою" 1885 p. [8,9,14,22] і до введення державної монополії на обіг спирту в середині 90X p. XIX ст. [23,24], представники органів земського самоврядування співпрацювали 3 чинами губернської адміністрації в складі губернського $з$ повітових справ Присутствія. Його очолював губернатор, входили віце-губернатор, пр.рор судової палати, управляючі акцизними зборами i Казеної палати, губернський предводитель дворян, голова губернської земської управи і міський голова Катеринослава. Члени повітових Присутствій з питних справ виконували свої обов'язки на громадських засадах.

Земства не мали права відкривати заклади 3 продажу спиртних напоїв $[23,25]$. 
У 1894 р. Катеринославське земство прийняло рішення закрити кабаки у селах, та селяни знайшли вихід - проходили 3-4 версти до заводського, шахтного селища, міста, щоб провести в кабаках вихідні чи свята. 31895 р. рішенням Катеринославського губернського земства трактири повинні були бути відкритими с 12 до 16 годин.

Земство робило спроби відміни весільних гулянь, бо «праздники уничтожают, если ни за день, то за неделю результаты годового труда, превращая уже заработанные деньги в продукты мгновенного потребления, а именно водку. Ведь даже самая скромная свадьба обходилась каждой семье не меньше чем в 100 руб. Действительно, именно такую сумму может заработать за год взрослый сельскохозяйственный работник. Период сельских свадеб - период сплошного пьянства. Свадьба всегда сопровождается пьянством». При этом, если денег на пьянство не хватало - свадьба откладывалась. По глубоко укоренившимся традициям мировоззрения праздновать свадьбу без водки, без угощения водкой до потери памяти - нечто абсолютно невозможное. Именно поэтому, в моральном отношении сельские свадьбы - еще более угрожающее явление, чем другие праздники». «сельские свадьбы аналогичны пожару. Как пожар превращает за один час состоятельного крестьянина в нищего, превращая в пепел плоды длительных лет труда, так и свадьба за одну неделю разрушает его хозяйство на долгие года, превращая в водку годовой доход» [26].

Катеринославська губернська земська управа у 1895 р. наголошувала: «Никогда винные лавки не торгуют так живо как с окончанием полевых работ к рождественскому посту и от 7 января до масленицы. При этом, пьяный разгул в праздники, кроме праздников религиозных и крестьянских, является последствием лености и бывает тогда когда у мужчин появляются деньги в кармане» [26].

«Малокультурные люди, считают, что их достоинство проявляется не в высших духовных качествах, а в том, чтобы выставить ведро водки. Именно это является признаком денежного могущества и преимущества».

Катеринославське земство вважало, що «сельские мужики грубые, норовистые, не уважают чужую собственность, ленивые и все время пьяные» считало, что лечить их нужно «радикальными способами». «Дать пьяницам землю и заставить работать - это единственное возможное решение вопроса». В таком случае, по их мнению, новый землевладелец получает главный жизненный ресурс. У него не будет времени на празднование и на беззаботную жизнь в свое удовольствие. При этом, чтобы заставить пьяниц работать земство предлагало обнести территорию участка колючей проволокой и уменьшить, таким образом количество сбежавших».

У 1895 р. в Бахмуті і повіті було 3 пиво медоварних заводи із загальним виробництвом 72 тис. пудів пива [27].

З 1869 по 1880 р. існував пивоварний завод купця Адельмана з річним доходом 3450 руб. У 1880 р. він був куплений А. Я. Абрамовичем [23]. 31895 р. завод належав співвласникам Юрію, Григорію, Ізраїлю, Давиду, Якову, Іллі і Мойсею Абрамовичам [28].

Завод випускав пиво столове, пільзенське, чорне. Для виробництва продукції використовувався ячмінь російський в кількості 12 тис. пудів на 6 тис. руб. на рік. Цей ячмінь доставлявся залізницею 3 Дубна, Любліна i Варшави,з Нюрнберга і Баварії на суму 2 тис. руб. на рік. Пивоварний завод мав «біологічне очищення». Виробництвом завідував майстер чех, що закінчив Школу пивоварів в Трітті у Австрії. Пиво і мед продавалися аптекам дрібним оптом, у роздріб у лавки Бахмуту, велика частина продукції вивозилася залізницею [28]. У 1910 р. керуючим пивоварним заводом Абрамовичів став Абрам Мосін за дорученням дружин купців Ревеки, Сури. Мірри, Рози Абрамович [29].

Пиво-медоварний завод Соломона Йосиповича Трахтерова був заснований 9 липня 1896 р. [30,31]. Статутний капітал становив 300 тис. руб. - 600 іменних акцій по 500 руб. Дозвіл на виробництво отримано 13 лютого 1898 р. [30]. У 1898 р. завод виробив 13570 відер пива і 450 відер меду на суму 8585 руб. Об'єм реалізації в 1909 1910 pр. складав 30 тис. відер пива по 1 рублю і 300 відер меду по 1 руб. 20 коп. Виробництвом завідував Альберт Францевич Єбір дипломований пивовар 3 Праги. Провідними професіями були бондар, бродинник (два помічника бродильщика), підвальний, кочегар, солодовник (3 помічники солодовника), 3 дробильникі солоду, 2 сушарники солоду. Продукцію фасували в скляні пляшки 3 мийники пляшок і 2 закупорщики. Доставкою продукції займалися 2 візники. До 1914 р. загальне виробництво пива на заводі Трахтерова складало 180 тис. пудів [31].

Завод Новоросійського товариства Юза Айвора мав пивоварний завод на 2 парові котли та 23 робітники на хут. Черепашки, де виробляв пива на 61 тис.руб. У 1903 р. на заводі Юза виробляли пива більше, ніж Абрамович - Трахтеров [32].

Іван Кузякін мав пивоварний завод біля Петровських заводів (Снакієво) на 30 тис руб. і 15 робітників.

Виробництвом сирого спирту з 1900 р. у селі Авдотьїно займався С.Животинський, виробляв продукції на 71 тис. руб., мав 2 парові казани та 28 
робітників. Ректифікованого спирту він виробляв на 10 тис. руб. [33].

Дворянин Карпов П.О. у маєтку хут. Трудовому на винокурному заводі виробляв спирту на 25 тис. руб., мав 2 парові казани та 22 робітники [33].

31909 p. (3 1 квітня до 1 вересня) Бахмутською міською Думою було дозволено встановлення на тротуарах парусинових наметів для дрібної торгівлі морозивом i прохолоджуючими напоями (торгувати вином i пивом заборонялося). Це могло ускладнити продаж міцних напоїв, "необхідний за ними поліцейський i акцизний нагляд". За намет платили в сезон 25 руб. [34].

До так званої "сфери громадського харчування", де вели роздрібну торгівлю горілчаними напоями та вином, у Бахмуті належали 6 готелів 3 номерами, 5 заїжджих двори, 7 трактирів, 2 ресторани, 2 їдальні, 2 харчевні, "чайна" і 25 пивних лавок [35].

У 1912 р. в Маріуполі, повіті, порту, на заводах було витрачено населенням на горілку 2 725192 руб.

Бахмутська земська управа відзначала, що «Работники напивались преимущественно в выходные дни, гуляли чаще всего в городе, под бдительным контролем полиции. Также на робочих предприятиях Бахмутского уезда запрещалось пить в одиночку. Но пьянство в рабочих коллективах не было распространенным явлением. Так, в месяц на колектив роботников тут уходило лишь пол ведра водки (6, 6 литра)...намного больше чем вера, алкоголь притуплял ужас от жизни и несчастных случаев. Алкоголь был опиумом, который делал жизнь масс выносимой. Он помагал крестьянину не замечать той грязи в которой живет его семья» вважавчлен Бахмутської земської управи Гаврилов. «Водка скрывала от крестьян их безволие и тот жизненный тупик в котром они находились. Вместе с тем, водка подрывала здоровье и калечила жизни».

Гласний Бахмутського земства К. Васильев зазнача, що «разнообразие положительно влияет на душу человека. Развлечения, в некоторой степени, настолько же необходимы для бедных классов населения, как удовлетворительный заработок, нормированный рабочий день и т.д. Потому, что не хлебом единым живет человек». Далее гласный говорил, что для каждого человека интересно было бы посещать театральные постановки с продуманным репертуаром, литературно-музыкальные вечера, художественные выставки, картинные галереи и т.д. При этом, задача земств не только организовывать эти выставки, но и сделать их общедоступными Только организовывая разумные развлечения можно преодолеть пьянство. Ведь народный театр или чтения отвлекают население от кабака и трактира и защищают людей от физической и духовной дряхлости, вызванной употреблением алкоголя. Народные развлечения и школа - надежный способ борьбы с пьянством» [36].

Прагнучи подолати алкоголізм , земства почали відкривати для хворих особливі відділення при психіатричних лікарнях. Для жителів Донбасу тривалий час існувала тільки одна психіатрична лікарня - губернська.

Ще в 1872 р. Катеринославський губернатор зобов'язав земства повітів піклуватися про відкриття лікарень і богаделен, надавав земствам право збирати гроші для цієї справи [37].

Славяносербске земство в 1874 р. відкрило лікарню для психічно хворих, де існувало відділення для лікування від алкогольної залежності,були створені усі умови - хворі були зайняті «працетерапією»: чоловіки ремонтували взуття, жінки в'язали, ремонтували одяг, займалися господарством. В лікарні були фортепіано, більярд, ігри в шашки, фізкультурні оздоровлюючі класи.

Справжньою бідою сел Бахмутського повіту стало на початку XX ст. поширення пияцтва $\mathrm{i}$ пов'язаних з ним правопорушень. У січні 1914 р. «Народная газета» порівнювала поведінку селян сусідніх сіл Кодемо та Зайцево: «Может, кто знает наше село Кодемо. Село это как будто забыто, заброшено, хотя в нем имеется одноклассная земская школа, учительница, причт и другая интеллигенция, но сказать мужику просветительное слово никто не может, потому что занят личным своим делом... Были большие праздники: Рождество, Новый год, Крещение и кодемцы провели их хорошо и весело - были и пьяны, и веселы, и нос в табаке, провели праздники в драке, озорстве, били окна мирных жителей, оскорбляли прохожих, ...пьют кодемцы зимой, пропивая потом нажитый хлеб». На противагу автор вказував, що «в 4 верстах расположено село Зайцево с таким же населением, но с хорошим духовным наставником в лице священника о. Владимира Гончарова, это село гораздо благоразумнее, ...есть кредитное товарищество» [38]. Це був прозорий натяк на кодемського священика - 40 річного Федора Івановича Зайцева.

Не покращило справу закриття в 1914 p. казенних винних лавок у зв'язку з початком I Світової війни [39]. Навпаки, пишно розцвіло самогоноваріння і вживання отруйних спиртових рідин. Селяни повіту ящиками розкуповували "політуру". Розповсюдилася торгівля різними одурманюючими "квасами", "спотикачами", «ханжами». Увійшов у вжиток "денатурат" (забарвлений спирт для розтирання), пляшка його доходила в ціні до 4-х руб. [40]. Кореспондент 
«Народної газети» I.Евенбах описує випадок, коли в селянській сім'ї під час проводів сина на війну було випито 3 пляшки "денатурату" вартістю в 12 руб. і відмічав, що справжня ціна цим пляшкам 36 копійок. Така екзотична суміш, як "ханжа" готувалася 3 "тютюну, оцту i всякої погані, заправлялася цукром i ароматичними речовинами". Цукор для браги закуплявся у великій кількості [40].

Поголовне пияцтво примусило поліцію Бахмутського повіту посилити покарання за появу в публічних місцях у нетверезому стані. Уперше за це відбувався арешт від 7 днів до 2-х тижнів або штраф від 35 до 50 руб., другий раз - арешт від 2$\mathrm{x}$ тижнів до 1 місяця або штраф 50-100 руб., а втретє - від 1 до 3-х місяців або штраф від 100 до 300 руб.

I. Евенбах писав, як пройшло святкування Великодня в Бахмуті у квітні 1915 р.: «на первый день Пасхи и в последующие дни нигде не было видно пьяных, ...драки и ссоры не замечены. Тихо и мирно двигалась праздничная толпа в центр города. У всех было настроение приподнятое от прекрасного весеннего дня, который опьянял своим чарующим запахом. Сразу потянуло в степь, там где зеленела травка... и степь покрылась гуляющими». Автор наважився пройтися Забахмуткою, де живуть «люди тяжелого труда, ...я думаю, что в прошлом году побоялся бы прогулки сюда из-за буйных пьяниц». Евенбах побачив на Забахмутці закритими шинок і винну лавку [41].

Деякі купці Бахмуту у 1917 році просили Катеринославського губернатора відмінити «сухий закон». Губернатор відмовив і передав це питання на розгляд місцевого самоврядування.

В Бахмутському земстві проголосували за збереження заборони 20 гласних , 8 «проти» «сухого закону».

У вересні 1917 р. 8 млн. літрів горілки та вина було вилито у Сапатів яр та річку Бахмут. Спалахнули «п'яні» безлади, бо тисячний натовп, набравши спиртне в усі ємкості, почав громити лавки з харчами і продукцією.

За допомогою артилерії та військ заворушення були припинені.

Таким чином, треба зазначити, що у Російській імперії законодавчо було забезпечене наповнення бюджетів повітових земств та міських Дум за рахунок видачі Свідоцтв на «питну справу», акцизів та місцевих податків.

\section{References:}

1. Yarmish ON (1990) Sudovi organi tsars'koï Rosiï v period imperializmu (1900-1917) /O.N.Yarmish.- K.

2. Yarmysh AN (1992) Nablyudat' neotstupno. Administrativno-politseyskiy apparat i organy politicheskogo syska tsarizma $\mathrm{v}$ Ukraine $\mathrm{V}$ kontse XIX - nachale XX v./A.N.Yarmysh. - K., -186 .

3. Goncharuk VY (2001) Pravove regulyuvannya virobnitstva i obigu spirtnikh napoïv $u$ Rosiys'kiy imperiï v drugiy polovini XIX - na pochatku XX st. (na materialakh ukraïns'kikh guberniy)/V.Ya.Goncharuk Dis. kand. yurid. nauk. -Kharkiv, KhNU vnutr. Sprav, - 195.

4. Mullov P (1864) Istoricheskos obozrenie pravitel'stvsnnykh mer po ustroystvu gorodskogo obshchestvennogo upravlennya/ P.Mullov. -St. Petersburg.

5. (1876) Ustav o gorodskom i sel'skom khozyaystve //Svod zakonov Rossiyskoy imperii. -V 16 t. -St. Petersburg., - t.12.

6. (1892) Polozhenie o merakh k sokhraneniyu gosudarstvennogo poryadka i obshchestvennogo spokoystviya 14 avgusta 1881 // Svod zakonov Rossiyskoy imperii. Izd. 1892. -t. 15.

7. (1885) Novye uzakonivaniya o piteynoy torgovle //Vestnik finansov, promyshlenosti i torgovli. №32.
8. (1885) Novye uzakonivaniya o piteynoy torgovle //Vestiik finansov, promyshlenposti i torgovli. №33.

9. (1885) Pravila o roznichnoy prodazhe napitkov: Vysoch.utv. 14 maya 1885 g.//Poln. sobr. zakonov Rossiyskoy imperii (PSZ). -Sobr. 3-e. t.5, - №2946.

10. (1885) Prikaz nalovym inspektoram po guberniyam Evropeyskoy Rosii utv.upravlyayushchim Ministerstvom finansov 12 avg. 1885. Vestnik finansov, promyshlennosti i torgovli. - T. 3., - pp. 579-582.

11. (1886) Polozhenie o zemskikh uchrezhdeniyakh so vsemi otnosyashchimisya $\mathrm{k}$ nemu uzakonivaniyami, sudebnymi i pravitel'stvennymi raz"yasneniyami//Sost. Mysh M.I. -St. Petersburg.:Tip. Lebedeva, - 948.

12. (1902) Ministerstvo finansov 1802 - 1902. V 2 ch. - St. Petersburg. Ekspeditsiya zagotovlennya gosudarstvennykh bumag.

13. Kurchinski YM (1912) Reforma zemskikh i gorodskikh finansov /M.Kurchinskiy// Gorodskoe dslo, №3, -pp. 165-175.

14. Fridman MI (1916) Vinnaya monopoliya. /M.I.Fridman. -1915-1916.

15. (1867) Prikazy v Ekaterininskuyu komissiyu po sostavleniyu novogo ulozheniya. Ot grazhdan Bakhmuta. - t.144, - ST. PETERSBURG. 
16. (1858) Voenno-statisticheskoe opisanie Rossiyskoy imperii. Ekaterinoslavskaya guberniya. -t.XI,-ch.4.,-ST. PETERSBURG.,1850; Novorossiyskiy kalendar' na 1859 g.Odessa.

17. (1861) Materialy dlya geografii i statistiki Rossii, sobrannye ofmtserami general'nogo shtaba. Ekaterinoslavskaya guberniya//Sostavil kapitan V.Pavlovich. -ST. PETERSBURG.,1862; Novorossiyskiy kalendar' na 1862. Odessa.

18. (1869) Sbornike statisticheskikh svedeniy po Ekaterinoslavskoy gubernii za 1869. Ekaterinoslav.

19. (1913) Otchet zemskogo vracha S.F. Kazanskogo o sostoyanii zdorov'ya naseleniya Mariupol'skogo uezda. 1912. S.F. Kazanskiy. Ekaterinoslav: Tip. gubernskogo zemstva.

20. Lokhmatova AI (1999) Katerinoslavs'ke zemstvo / A.I. Lokhmatova. - Zaporizhzhya.: RA «Tandem».

21. (1881) Otchet uezdnoy upravy za $1880 \operatorname{god}$ XVI ocherednomu sobraniyu Bakhmutskogo zemstva. -Bakhmut, 175.

22. (1872) Materialy, sobrannye dlya vysochayshe uchrezhdennoy komissii o preobrazovanii gubernskikh y uezdnykh uchrezhdeniy. V 4ch. SIIb.:Tip. MVD, - 1870-1871; Sbornik pravitel'stvennykh rasporyazheniy po delam, do zemskikh uchrezhdeniy otnosyashchimsya. Izd.2-e. -St. Petersburg.: Izd. khoz. den. MVD, 1872 , -t. 1 .

23. (1892) Obshee uchrezhdenie gubernskoe// Svod zakonov Rossiyskoy imperii. -V 16 t. - -St. Petersburg., -t. 2.

24. Shipov DN (1899) K voprosu o vzaimnykh otnosheniyakh gubernskikh i uezdnykh zemstv/D.N.Shipov. - Moscow.

25. Kuznetsov NI (1902) Sistematicheskiy svod ukazov Pravitel'stvuyushchego Senata, posledovavshikh po zemskim delam, 1866-1900 gg./N.I.Kukhnetsov - St. Petersburg.: Tip. Kolpinskogo.

26. (1896) Otchet Ekaterinoslavskoy gubernskoy zemskoy upravy za 1895.- Ekaterinoslav: Tip. gubernskogo pravleniya, - pp. 366.
27. (1896) RGIA. -F. 1290. -Op. 11. - D. 612. Oprosnyy listok o sostoyanii g. Bakhmuta v 1896 godu.

28. (1897) RGIA. -F. 1290. -Op. 11.- D. 612.Oprosnyy listok o sostoyanii goroda, razoslannyy $\mathrm{v}$ svyazi s podgotovkoy Pervoy Vserossiyskoy perepisi naseleniya 1897.

29. (1895) RGIA. - F. 32. - Op. 1 - D. 1571. Oprosnyy Listok pivovarennogo zavoda Abramovicha, «Obshchestvo pivovareniya Trakhterova»: RGIA. - F. 20. - Op. 12. - D. 52. Vedomost' o sostoyanii pivo-medovarennogo zavoda Torgovogo doma naslednikov A.Ya. Abramovicha v 1895.

30. (1909) RGIA. -F. 1290. -Op.5. -D.230.Anketa g. Bakhmuta s razlichnymi statisticheskimi svedeniyami za 1907-1909 gg.

31. (1909) RGIA. -F. 20.- Op. 12. - D. 53. Vedomost' o sostoyanii pivo-medovarennogo zavoda Trakhterova

32. (1903) Zhurnaly XXXVII ocherednogo sobraniya Bakhmutskogo uezdnogo zemstva. Ch.1. - Bakhmut, - 213.

33. (1900) Zhurnaly XXXIV ocherednogo sobraniya Bakhmutskogo uezdnogo zemstva. Bakhmut, -275 .

34. (1911) Otchet Bakhmutskoy gorodskoy upravy za 1910 god. -Bakhmut, -105.

35. (1914) Otchet bakhmutskoy gorodskoy upravy za 1913 god. -Bakhmut, -123.

36. (1891) Otchet Bakhmutskogo uezdnogo zemskogo sobraniya za 1890. - Bakhmut: Tip. Chausskogo.

37. (1905) Otchet Ekaterinoslavskoy gubernskoy zemskoy upravy za 1904.- Ekaterinoslav: Tip. gubernskogo pravleniya.

38. (1914) Narodnaya gazeta Bakhmutskogo zemstva. - № 4.

39. (1915) Narodnaya gazeta Bakhmutskogo zemstva. - №25.

40. (1915) Narodnaya gazeta Bakhmutskogo zemstva. - № 29 .

41. (1915) Narodnaya Gazeta Bakhmutskogo zemstva. -№11. 